\title{
A Igreja e o Espírito: fundação e constituição da Igreja no ponto de vista da causa formal
}

\author{
JACIR SILVIO SANSON JUNIOR \\ Universidade Federal do Espírito Santo (Brasil) \\ jasisaju@hotmail.com
}

\section{Resumo}

Reunimos alguns argumentos com base no Novo Testamento (a respeito dos gestos ungidos de Jesus) e em documentos pontifícios (sobre a eclesiologia do Concílio Vaticano II) para debater a pertinência da noção filosófica de causa formal no discurso teológico sobre a fundação e a constituição da Igreja.

Palavras-chaves: Igreja, Espírito Santo, instituição, causa formal, causa final.

\section{La Iglesia y el Espíritu: fundación y constitución de la Iglesia en el punto de vista de la causa formal}

\section{Resumen}

En este artículo hemos compilado algunos argumentos basados en el Nuevo Testamento (sobre los gestos ungidos de Jesús) y en los documentos pontificios (sobre la eclesiología del Concilio Vaticano II) para discutir la relevancia de la noción filosófica de causa formal en el discurso teológico sobre la fundación y la constitución de la Iglesia.

Palabras clave: Iglesia, Espíritu Santo, institución, causa formal, causa final.

\section{Church and Spirit: foundation and constitution of the Church in the formal cause's viewpoint}

\begin{abstract}
In this paper we gathered some arguments based on the New Testament (about the anointed actions of Jesus) and pontifical documents (on ecclesiology from the Second Vatican Council) to discuss the relevance of philosophical notion of formal cause for theological discourse on the foundation and the constitution of the Church.
\end{abstract}

Key words: Church, Holy Spirit, institution, formal cause, final cause.

Mestre em Filosofia pela Universidade Federal do Espírito Santo (UFES), e Bacharel em Teologia pelo Centro Universitário Salesiano de São Paulo (UNISAL-Pio XI). É tutor e formador no curso de Licenciatura em Filosofia na modalidade de Ensino a Distância (SEAD/UFES/UAB). Aborda termas interdisciplinares de Filosofia e Psicanálise e em Antropologia bíblica e filosófica, resultando em trabalhos como $A$ oração desde o ser: ontologia da vida orante (2016), Paulo de Tarso e o sinthoma: da perda da carne-sarx ao encontro do corpo-soma (2016). Dedico este trabalho às religiosas Antonia, Maria de Lourdes e Ana Carolina, missionárias no Brasil, Moçambique e Filipinas.

Recibido: 11/Noviembre/2016 - Aceptado: 8/Enero/2017 


\section{Introdução}

A análise sobre a causa formal da constituição da Igreja conduz a uma resposta bastante peculiar à pergunta sobre a origem (fundação) e a composição (constituição) da Igreja. Propomo-nos revisitar o tema e distinguir aquilo que nele se trabalha nos termos da causa final.

Para se chegar a tal foco de análise, será preciso diferenciá-lo ao contexto de um debate geralmente mais comum e reconhecido, pois quando se fala da relação entre Cristo, Igreja e Reino é pretendido mostrar que a Igreja não tem por finalidade a si mesma, mas o Reino. Em harmonia com esse ângulo da causa final, convém mostrar que, sob o da causa formal, a Igreja é contemporânea a Cristo, ou seja, em vez de vê-la surgir apenas em momento subsequente ou até mesmo tardio, reunimos elementos de ordem formal para concebê-la na imediaticidade dos gestos de Jesus.

A Igreja é às vezes tratada como um a posteriori ao ministério de Jesus. Isso se baliza com a perspectiva de tomar sua gênese na sequência do evento-Cristo. Nossos esforços se destinam a argumentar pela tese de que a Igreja se faz necessariamente presente na vida do Senhor.

O pesquisador em Eclesiologia possivelmente já deve ter-se deparado com a sensação hipotética de que a Igreja pudesse ser um acidente devido a um previsível percalço no desenrolar da História da salvação. Seria, ao contrário, alienante a utopia de achar que todos os homens, em coro uníssono, acolheriam o Cristo que veio cumprir a vontade do Pai, inaugurando na terra o Reino dos céus.

Nosso intuito consiste em mostrar a fragilidade de uma compreensão eclesiológica relativa à gênese da Igreja, cuja limitação acarreta dificuldades para um olhar mais integral quanto ao mesmo processo de origem. Não veremos como satisfatória a locação da Igreja na simples continuidade do ministério de Cristo e dos apóstolos. Antes disso, com base no conceito de causa formal analisaremos a Igreja como fermento ou alma do mundo, voltada a realizar na sociedade humana o que o Espírito de Jesus engendra na natureza visível-invisível do próprio tecido eclesial.

Não é manifesto que no discurso eclesiológico se delineie o uso ou mesmo se aponte com que ênfase se emprega uma determinada terminologia filosófica. Ao menos em Eclesiologia isso não é tão frequente como na Cristologia, por exemplo. Com base então nas sínteses de Jolivet (1982), traçamos o objetivo de depurar o emprego das noções de causa final e causa formal na compreensão teológica sobre a Igreja, recorrendo para isso às fontes mais privilegiadas da doutrina, como o Catecismo (1999) e documentos do Concílio Vaticano II (2007), além de outros textos pontifícios (papais). Buscamos avaliar, junto aos elementos constitutivos do dis- 
curso sobre a Igreja, qual o tipo mais utilizado de causalidade. Essas referências, tratadas sob esse foco conceitual e metodológico, permitirão que identifiquemos certos matizes, abrindo margem para efetuarmos aqui uma crítica ou mesmo uma reivindicação em pró da primazia do ponto de vista formal.

\section{A noção de causa final no discurso eclesiológico}

O ensino catequético sobre a instituição da Igreja pode ser resumido em frases sucintas. Para empregarmos as palavras do Catecismo da Igreja $\mathrm{Ca}$ tólica (CAT), impõe-se uma ordem sequencial pela qual a Igreja: a. é um projeto do desígnio arcano do Pai; b. prefigurada desde a origem do mundo; c. preparada pela aliança com os patriarcas; d. enfim instituída por Jesus Cristo; e. para manifestar-se publicamente pelo Espírito em vista de uma missão; f. e chegar à consumação na glória celeste (CAT: 759-769).

Os marcos fundamentais dessa trajetória, como assim se expõe, possuem um caráter trans-histórico, pois se iniciam fora do tempo (itens a-b), inserem-se na história (itens c-e) para em seguida alcançarem novamente a eternidade (item f). Em vista desse percurso, é perfeitamente visível que o sujeito-Igreja tem uma origem, uma função e uma missão. Mas em certos momentos, parece ocorrer uma ligeira inversão, de modo que se torna forçoso falar em objeto-Igreja. O Catecismo se projeta de fato nessa perspectiva, quando enfatiza sua reflexão com as palavras de Clemente de Alexandria:

A Igreja é a finalidade de todas as coisas, e as próprias vicissitudes dolorosas, como a queda dos anjos e o pecado do homem, só foram permitidas por Deus como ocasião e meio para desdobrar toda a força de seu braço, toda a medida de amor que Ele queria dar ao mundo: "Assim como a vontade de Deus é um ato e se chama mundo, assim também sua intenção é a salvação dos homens e se chama Igreja (CAT: 760).

Demarcamos inicialmente este duplo aspecto: no primeiro, temos a Igreja, como sujeito, perseguindo o propósito de sua existência, sua finalidade missionária e escatológica; no segundo, como que numa inversão, não é mais a Igreja-sujeito que possui uma finalidade, mas ela é que se torna o fim, qual objeto, visado por outros sujeitos, tal como recorda o Catecismo a visão de Hermas: "OO mundo foi criado em vista da Igreja', diziam os cristãos dos primeiros tempos” (CAT: 760). Essa tensão entre troca de perspectivas demonstra a importância de se manter vigente a causa final da Igreja, precisamente para que não se faça da Igreja um fim em si mesmo. 
A ênfase na causa final permite à Igreja abraçar cada vez mais sua vocação e se envolver mais intensamente com sua missão, na medida mesma em que se torna mais consciente de sua origem. Conforme uma avaliação eclesiológica, isso seria muito benéfico ao mundo, por se servir justamente da Igreja como meio de sua redenção. O Catecismo emprega o texto da Lumen Gentium (LG) para assegurar esse propósito: “[...] desde a origem do mundo a Igreja foi prefigurada. Foi admiravelmente preparada na história do povo de Israel e na antiga aliança. Foi fundada nos últimos tempos. Foi manifestada pela efusão do Espírito. E no fim dos tempos será gloriosamente consumada" (LG: 2 apud CAT: 759).

Essas palavras exprimem o consilium Dei (pensamento de Deus) acerca da Igreja, bem como relançam para cada cristão o propósito de se aprofundar no mistério da Igreja (CAT: 770). Mas é também em seus átrios que estão acomodados um inestimável e ao mesmo tempo espinhoso debate: sobre a relação entre a Igreja e o Reino.

\subsection{O papel moderador da causa final na relação entre o Reino e a Igreja}

A relação entre Reino de Deus e Igreja vem sendo um tema teológico de consideráveis variações. Não corresponde a nossos objetivos ponderar suas nuances, mas apenas mostrar a pertinência do conceito de causa final para essa discussão.

Trabalhada por João Paulo II na Redemptoris missio (RM: 17), a íntima relação entre Cristo, o Reino e a Igreja é retomada pela Congregação para a Doutrina da Fé na declaração Dominus Iesus (DI), de 6 de agosto de 2000, no intuito de se advertir contra dois excessos: o reinocentrismo e o eclesiocentrismo.

Ao considerar as relações entre Reino de Deus, Reino de Cristo e Igreja devem evitar-se sempre as acentuações unilaterais como no caso dos que propõem "concepções que, propositadamente, enfatizam o Reino e se intitulam 'reinocêntricas', evidenciando a imagem de uma Igreja que não pensa em si, mas dedica-se totalmente a testemunhar e servir o Reino. [...]"

"Além do mais, o Reino, tal como eles o entendem, acaba por marginalizar ou desvalorizar a Igreja, como reação a um suposto 'eclesiocentrismo' do passado e porque consideram a Igreja apenas um sinal, aliás passível de ambiguidade". Tais teses são contrárias à fé católica, por negarem a unicidade da relação de Cristo e da Igreja com o Reino de Deus (DI: 19 apud Denzinger \& Hünermann 5089). 
A nosso ver, ambos os extremos estão previstos na condição de eclipsamento da causa final. Quando se perde de vista qual a finalidade da Igreja, criam-se as circunstâncias de sua hipertrofia ou mesmo de seu embotamento. No primeiro caso, a Igreja é supervalorizada a ponto de tornar-se fim em si próprio (eclesiocentrismo); no segundo, ela perde sua finalidade e é progressivamente aniquilada em função do Reino de Deus segundo uma compreensão imanentista (cf. RM: 17) que silencia o protagonismo de Jesus (reinocentrismo).

$\mathrm{Na}$ Redemptoris missio, de 7 de dezembro de 1990, João Paulo II estima por uma "visão de conjunto" (RM: 19) na qual Igreja e Reino são concêntricos ao anúncio de Cristo: da mesma forma que Jesus, com seus gestos e palavras, na sua presença pessoal e na realização de sua missão, promove o advento do Reino pela pregação da Boa Nova (cf. RM: 18; CAT: 763; LG: 5), ele também institui a Igreja, qual "pequeno rebanho" (Lc 12,32), como "o germe e o começo do Reino" (CAT: 764). João Paulo II sintetiza bem essa relação, sempre balizando com a sombra de excessos indesejáveis:

Se separarmos o Reino, de Jesus, ficaremos sem o Reino de Deus por ele pregado, acabando por se distorcer quer o sentido do Reino, que corre o risco de se transformar numa meta puramente humana ou ideológica, quer a identidade de Cristo, que deixa de aparecer como o Senhor, a quem tudo se deve submeter (cf. 1Cor 15,27).

De igual modo, não podemos separar o Reino, da Igreja. Com certeza que esta não é fim em si própria, uma vez que se ordena ao Reino de Deus, do qual é princípio, sinal e instrumento. Mesmo sendo distinta de Cristo e do Reino, a Igreja todavia está unida indissoluvelmente a ambos. Cristo dotou a Igreja, seu Corpo, da plenitude de bens e de meios de salvação; o Espírito Santo reside nela, dá-lhe a vida com os seus dons e carismas, santifica, guia e renova-a continuamente (RM: 18).

Sem a referência de sua causa final, a Igreja tende a perder o sentido de sua missão, expressa acima: estar "a serviço do Reino" (RM: 20), sendolhe princípio, sinal e instrumento. Ademais, ela passa a vacilar quanto à razão de si mesma, já num cenário onde sua existência é avaliada como dispensável em função da primazia dos "valores do Reino" (RM: 17).

Esse valor teologicamente estratégico da causa final aparece com sonoridade em 24 de novembro de 2013, data de publicação da Evangelii gaudium (EG). O Concílio, mediante o decreto Ad gentes (AG), já havia declarado audaciosamente acerca do caráter eclesial da missionaridade: "A Igreja peregrina é por natureza missionária” (AG: 2). Depreende-se que a missão não é mera atividade, e sim uma ação muito específica que concretiza, realiza ou finaliza uma condição essencial. 
Francisco desdobra essa afirmação nos vários lugares onde ela reverbera em sua exortação apostólica. A natureza missionária da Igreja é patente ao fato inaugural de seu compromisso com o Evangelho. O significado mesmo de "Boa-nova" pressupõe a itinerância, além do que a mesma Palavra é tratada analogamente como "semente que, uma vez lançada à terra, cresce por si mesma, inclusive quando o agricultor dorme (cf. Mc 4,26-29)" (EG: 22). Isso determina que a Igreja esteja sempre "em saída" (EG: 20), tanto no sentido de "anunciar o Evangelho a todos, em todos os lugares, em todas as ocasiões, sem demora, sem repugnâncias e sem medo" (EG: 23), como no de anunciá-lo com motivos autênticos: "O problema não está sempre no excesso de actividades, mas sobretudo nas actividades mal vividas, sem as motivações adequadas, sem uma espiritualidade que impregne a acção e a torne desejável” (EG: 82).

A exortação ainda lançaria o neologismo "primeirar", designando não apenas uma série de qualidades do discípulo-missionário, como saber "ir à frente, tomar a iniciativa sem medo, ir ao encontro, procurar os afastados e chegar às encruzilhadas dos caminhos para convidar os excluídos" (EG: 24), mas também uma espiritualidade missionária, pela qual a vida espiritual não se restringe a alguns momentos religiosos, pois se irradia em todo o estilo de vida do cristão, na forma de uma "paixão pela evangelização" (EG: 78). Se a evangelização é um dever da Igreja, escreve Francisco, este sujeito-Igreja "é mais do que uma instituição orgânica e hierárquica; é, antes de tudo, um povo que peregrina para Deus" (EG: 111).

Vemos o quanto a noção de causa final assume um papel eclesiologicamente moderador. Sem ela, Igreja e Reino perdem sua estabilidade cristológica e, com isso: ou a Igreja se autopromove ufanissimamente ao usurpar a expectativa em torno da chegada do Reino, ou o Reino sem a Igreja é esvaziado de sua remissão à reiterada mensagem de Jesus, decaindo para uma realidade totalmente secularizada.

Para enunciar as consequências da ausência da causa final na pesquisa em Eclesiologia, diríamos que a Igreja fica irremediavelmente destituída de seu fim escatológico. O Reino é a concretização escatológica da Igreja: sem o Reino, tal projeto se verte à falência. Em contrapartida, sem a Igreja, o Reino jamais alcançaria sua plena consumação. E isso é percebido pela Dominus Iesus ao formular um texto em parceria com o decreto Ad gentes (cf. AG: 2), embora sem utilizar a terminologia filosófica: "A salvação tem uma relação estreita com a Igreja, que, por sua vez, 'tem a sua origem na missão do Filho e na missão do Espírito Santo, segundo o desígnio de Deus Pai”" (DI: 20 apud Denzinger \& Hünermann 5089).

O Catecismo ainda delimita com bastante precisão uma frase conciliar que muito aporta à autocompreensão da Igreja acerca de seu fim escato- 
lógico: "A Igreja é, em Cristo, como que o sacramento ou o sinal e instrumento da íntima união com Deus e da unidade de todo gênero humano" (LG: 1 apud CAT: 775). A Igreja se insere na missão de Jesus, cuja meta era realizar o plano de salvação de Deus Pai (CAT: 763; CAT: 772). Sua progressão no curso da história não tem como fim a própria história, mas o desígnio da Santíssima Trindade (CAT: 758).

É valioso destacar, para o desenvolvimento subsequente, que a fundação da Igreja é um evento ligado diretamente ao mistério redentor de Cristo, pois é em função dele, isto é, de sua finalidade, que a Igreja se configura como sacramento, sinal e instrumento. Essas três palavras praticamente reproduzem, na interface Igreja-Cristo, o que a Redemptoris missio concebeu acerca da relação Igreja-Reino, averiguada há pouco. É coerente então supor a extrema relevância da expressão "causa final" com o discurso a respeito da fundação da Igreja.

\subsection{A causa final no discurso sobre a fundação da Igreja}

A concepção de causa final numa função cardeal (no sentido etimológico de dobradiça) entre Reino e Igreja é decisiva para se construir um dado discurso sobre a fundação da Igreja. Além disso, aquilo que melhor entendemos acerca da instituição da Igreja por Cristo está baseado, intrínseca e sutilmente, na noção de causa final; isso porque é na Igreja e, em certo sentido, pela Igreja que Cristo realiza o desígnio de Deus, no intuito de uma obra à qual a Igreja se conforma como instrumento, sinal e sacramento (CAT: 776).

Essas demarcações sem dúvida favorecem o entendimento sobre a criação da Igreja no aspecto de seu propósito final, apesar de ela atualmente peregrinar "por meio das perseguições do mundo e das consolações de Deus" (CAT: 769) ${ }^{1}$. É em função desse propósito que o Espírito a dotou de carismas (CAT: 768); é para realizar uma missão que o seu Fundador a enriqueceu de dons e a estruturou hierarquicamente (CAT: 765); enfim, em razão de uma só e imperiosa meta, a salvação, é a Igreja definida como “"convocação' de todos os homens” (CAT: 767).

Vai assim ficando cada vez mais explícita a prerrogativa da causa final na elaboração teológica sobre a instituição da Igreja. Isso é assinalável até mesmo quando ocorre anuir pela sua formação mística, apontada uma vez por Santo Ambrósio e confirmada pelo Catecismo nestas palavras: "[...] a Igreja nasceu primeiramente do dom total de Cristo para nossa salvação, antecipado na instituição da Eucaristia e realizado na Cruz" (CAT: 766).

1 Esse complemento é recapitulado da Cidade de Deus, de Santo Agostinho, pela Lumen Gentium (LG: 8).

VERITAS, No 36 (Abril 2017) 
O ponto de vista da causa final arquiteta um panorama frontal da Igreja. Ele permite uma análise sempre atualizada pela qual o sujeito eclesial é avaliado se está em harmonia ou se extraviando de seu objetivo. A Igreja é, desde o parâmetro de sua finalidade, percebida em ordem a seu prospecto, bem como mobilizada em função de uma solicitude, pois segundo Régis Jolivet (1982: 284), na causa final é "evidente o desejo que está no princípio do movimento: é porque fui solicitado por alguma coisa, que me apareceu como desejável, que resolvi agir".

Esse raciocínio põe em evidência o dado etimológico: "Aquilo que entendemos por 'igreja' é no Novo Testamento expresso principalmente pelo termo grego $\varepsilon \varkappa \varkappa \lambda \eta \sigma \iota \alpha$, que [...] provém de $\varepsilon \varkappa-\varkappa \alpha \lambda \varepsilon \iota \nu=$ 'chamar para fora', 'convocar'. [...]” (Warnach, 1988: 485). Essa apropriação religiosa se mantém similar ao grego onde ekkelesia é também a assembleia do demos (povo): "os cidadãos são os ekkletoi, convocados, pelo arauto 'para fora' $(e k)$ de suas casas para uma reunião. Partindo deste ponto se pode inferir algo para o sentido bíblico-cristão: Deus em Cristo chama os homens 'para fora' do mundo" (Schmidt, 1965: 31).

É muito promissor que o programa etimologicamente pautado na causa final nos ajude a reencontrar o horizonte escatológico da vida eclesial. Com efeito, isso se traduz em novo ardor, mas também comporta riscos, como os que Medard Kehl (1997: 73) denomina cristomonismo e pneumatomonismo. Os termos visam mostrar que modelos eclesiais reducionistas derivam de visões teológicas míopes quanto à Trindade. Pensada sob uma Cristologia estreita, a Igreja se petrifica numa estrutura fundacional de poder e representação: "Um Deus, um Senhor e Cristo, um papa, uma Igreja" (Kehl, 1997: 61); e sob uma Pneumatologia simplificada, diluir-se-ia em alguma outra unilateralidade ${ }^{2}$.

Resulta desse quadro que a Igreja venha a ser tratada, sutil e até explicitamente, como um a posteriori ao ministério de Jesus e dos apóstolos, guardando com ele somente uma relação extrínseca, de mera continuidade histórico-temporal. Vale dizer: em vista da aguardada apoteose final, descura-se dos princípios, e a Igreja é locada como uma etapa subsequente ou mesmo tardia ao evento-Cristo. Tudo isso pode estar subentendido sob os termos reinocentrismo e eclesiocentrismo, cristocentrismo e pneumocentrisno. Desejamos, em contrapartida, atentar para o valor da perspectiva formal, pela qual nos precavemos contra essas referidas conjecturas.

2 " [...] a variedade [carismática] é posta de maneira não-dialética acima da unidade e, correspondentemente, a Igreja local acima da universal, a comunidade acima do ministério, o carismático acima do institucional, a liberdade individual acima da forma obrigatória, a comunidade de base ou o grupo primário diretamente vivenciado acima da paróquia ou da grande Igreja etc." (Kehl, 1997: 73). 


\section{A fundação da Igreja no ponto de vista da causa formal}

Sob o ponto de vista formal, há de se pensar impreterivelmente a fundação ou surgimento da Igreja na contemporaneidade de Jesus. É coerente supor que: se o aspecto formal permanece ativo no chamado "tempo da Igreja" (CAT: 732), ele se faz terminantemente presente no momento de sua instituição por Cristo. É assim, pois, que a partir da causa formal, tenderemos a perceber o nascimento da Igreja num olhar renovado.

\subsection{A causa formal no "tempo da Igreja"}

Em que consiste a causa formal tocante à constituição da Igreja? E como pensar a fundação da Igreja no ponto de vista da causa formal? Essas questões, evidentemente, não interrogam apenas pelo sentido daquele conceito, mas por sua tradução no discurso teológico.

Jean Lauand (2012: 23) pontua o uso desse conceito aristotélico no Catecismo (cf. CAT: 365), arguindo que "não só para a teologia, mas para a própria formulação da fé, a Igreja acaba tendo de valer de termos, por assim dizer, 'técnicos' de filosofia". Isso se dá por certa necessidade, pois "as verdades de fé não são teoremas abstratos e desencarnados, harmonizam-se com as verdades naturais - quer provenham do conhecimento comum, da ciência ou da filosofia- e, em certo sentido, delas dependem" (Lauand, 2012: 22).

A noção de causa formal também se faz sentir noutra passagem do Catecismo, precisamente para tratar a relação Igreja-Espírito. Há qualquer traço nessa relação pelo qual se justifica dizer: o Espírito é a forma da Igreja. Dá-se justamente em três parágrafos que preparam a segunda, terceira e quarta parte do Catecismo, onde são abordadas: a celebração do mistério cristão $^{3}$, a conduta moral ${ }^{4}$ e a oração ${ }^{5}$. A causa formal subjaz em todos os modos de a Igreja se exprimir: seja num determinado tempo e lugar, seja pelo próprio fato de ser tal como a Igreja é em si mesma.

3 "Por ser o Espírito Santo a unção de Cristo, é Cristo, a Cabeça do Corpo, que o difunde em seus membros, para alimentá-los, curá-los, organizá-los em suas funções mútuas, vivificá-los, enviá-los a testemunhar, associá-los à sua oferta ao Pai e à sua intercessão pelo mundo inteiro. É pelos sacramentos da Igreja que Cristo comunica aos membros de seu Corpo o seu Espírito Santo e Santificador [...]” (CAT: 739).

$4 \quad$ “Essas 'maravilhas de Deus', oferecidas aos crentes nos sacramentos da Igreja, produzem seus frutos na vida nova, em Cristo, segundo o Espírito [...]” (CAT: 740).

5 “'O Espírito socorre a nossa fraqueza, pois não sabemos o que seja conveniente pedir; mas o próprio Espírito intercede por nós com gemidos inefáveis’ (Rm 8,26). O Espírito Santo, artífice das obras de Deus, é o Mestre da oração [...]” (CAT: 741).

VERITAS, No 36 (Abril 2017) 
E seria eloquente ainda realçar os valores compartilhados entre os sentidos de graça e santificação com o de causa formal. Na perspectiva antropológica, a alma santificada, para todos os efeitos, é a alma que recebeu de um dom sobrenatural a forma de sua perfeição ontológica. Parecenos também ser o ponto de vista formal que patrocina estas penetrantes e não menos ousadas palavras que se leem no Catecismo:

"Sua [da Igreja] estrutura se ordena integralmente à santidade dos membros do corpo místico de Cristo. E a santidade é medida segundo o 'grande mistério', em que a Esposa responde com o dom do amor ao dom do Esposo". Maria nos precede a todos na santidade que é o mistério da Igreja como "a Esposa sem mancha nem ruga". Por isso, "a dimensão marial da Igreja antecede sua dimensão petrina” (CAT: 773).

O aspecto da formalidade expõe a preeminência da dimensão mariana. Numa intuição semelhante a essa, o trabalho de Brendan Leahy (2005) atinge audaciosa profundidade. O título O princípio mariano na Igreja, que é na verdade uma tradução de The Marian profile in the Ecclesiology of Hans Urs von Balthasar, alude à síntese que o papel exercido por Maria representaria para perfis ou dimensões - não precisamente princípios abstratos - de Igreja apoiados em Pedro (o ministério), João (o amor), Paulo (o carisma) e Tiago (a tradição). O histórico de formulações patrísticas e medievais é interpretado como fator de saúde eclesial.

O Vaticano II [...] destacou o papel da Igreja como sacramento de unidade com Deus e com toda a humanidade. Esse sacramento de unidade contém tanto a unidade externa, petrina, quanto a unidade interna, mariana. A unidade petrina é o princípio hierárquico na Igreja. O elemento mariano da Igreja é a presença esponsal e materna de Maria, que confere uma unidade mariana no núcleo da Igreja celeste e terrena, na qual a ordem da natureza é aperfeiçoada pela graça; o Eros, pelo ágape; o cosmo criado, pelo amor eclesial (Leahy, 2005: 42-43).

Esse princípio mariano, que "comporta certa relativização do elemento hierárquico da Igreja" (Leahy, 2005: 217), visa diretamente um "sentir" a Igreja de um modo mariano. Por ele se redescobre o centro místico da unidade eclesial, e até se pretende tomá-lo como uma quinta categoria constitutiva: "[...] além de ser una, santa, católica e apostólica, a Igreja é mariana” (Leahy, 2005: 181). Ele é como uma janela pela qual se olha para o mistério da Igreja, às vezes encoberto pela burocratização do aparelho institucional, por experiências sociológicas de cunho machista e mesmo pelo clericalismo. Mas tantas fontes positivas em movimentos de 
renovação emergentes revitalizam o "sentire ecclesiam" (Leahy, 2005: 213) promovendo uma "nova consciência eclesial" (Leahy, 2005: 209) ${ }^{6}$.

Por esse ângulo se faz necessário conceber um influxo sempre atual entre o Espírito e a Igreja, bem como apreender o dado de seu formato mariano em maior implicação com a existência histórica de Jesus, para o que assim atenta o Catecismo: "[...] a missão da Igreja não é acrescentada à de Cristo e do Espírito Santo, senão que é o Sacramento dela: por todo o seu ser e em todos os seus membros, a Igreja é enviada a anunciar e testemunhar, atualizar e difundir o mistério da comunhão da Santíssima Trindade [...]" (CAT: 738). Não é suficiente que a Igreja mantenha um vínculo de continuidade com o evento-Cristo, nem se compactue pela estimativa de um fim comum: pelo termo "Sacramento" se pretende conceber uma adequação formal, ou seja, uma conformação (mais profunda ou essencial) da Igreja com seu Fundador.

O termo que melhor identifica a atualidade formal na relação de Cristo com a Igreja é o grego mysterion, que no latim ganhou duas versões: com mysterium dando mais atenção à realidade escondida e inefável da salvação, e sacramentum, o sinal visível ou palpável desse mesmo mistério. Santa e santificante, a Igreja tanto contém como comunica a graça invisível da salvação, e é por isso chamada analogamente de "sacramento" (CAT: 774). Como é Cristo o "único mistério da salvação" (CAT: 774), temos de considerar que, em sua vida terrena, seus gestos e palavras, ao passo que espalhavam a cura e a salvação entre os homens, iam também constituindo formalmente a Igreja.

\subsection{A fundação da Igreja na formalidade dos gestos de Jesus}

O ponto de vista formal sugere uma perspectiva singular para se pensar a instituição da Igreja (fundação) e a instituição-Igreja (constituição), a saber: não apenas segundo a legitimidade de um ato fundador, não só mediante a virulência de um evento inaugural. A Igreja, segundo sua forma, nasceu dos gestos e palavras de Jesus. Nesse sentido, damos o nome "Igreja" a toda obra de cura e salvação que Cristo realizou com suas mãos humanas.

O Catecismo empregou os verbos "preparar" e "construir" para lançar luz sobre esse fato. "Representando as doze tribos de Israel, eles [os Doze]

6 Toda a atuação de Maria relatada pelos evangelistas sinóticos é uma ação no Espírito (CAT: 721-726). Ademais, a chamada história da Igreja primitiva não poderia ser compreendida sem o Espírito, conforme o relato dos Atos: "A missão da Igreja não é acrescentada à de Cristo e do Espírito Santo, senão que é o Sacramento dela” (CAT: 738).

VERITAS, No 36 (Abril 2017) 
são as pedras de fundação da nova Jerusalém. Os Doze e os outros discípulos participam da missão de Cristo, de seu poder, mas também de sua sorte. Por meio de todos esses atos, Cristo prepara e constrói sua Igreja" (CAT: 765).

Com tais acentos, vemos como a ideia de uma fundação, de uma continuidade na linha histórica ou mesmo de uma transmissão condizem melhor com a finalidade. O ponto de vista formal, por sua vez, não se apresentaria tão modestamente se, aprimorando nossa percepção, verificássemos que a razão de ser da Igreja é formalmente idêntica às realizações operadas por Jesus mediante suas ações. Assim como a Igreja faz hoje o que Cristo fez ontem, levando a termo sua missão (causa final), o que Cristo fez ontem já era a Igreja (causa formal) naquilo que ela faz hoje.

A causa formal é um genuíno interpelativo para conhecermos a Igreja na dimensão múltipla de sua gênese, a saber, em cada gesto e palavra de Jesus, em toda obra por ele realizada, em todo ensinamento por ele proferido. É o que se passa, por exemplo, ao se averiguar em Lucas 4,22 a menção às "palavras de graça" (Konings, 2005: 27) que saíam da boca de Jesus, bem como seus paralelos de Mateus 13,54 e Marcos 6,2, onde constam "sabedoria" e "obras-de-poder" (Konings, 2005: 115).

A pneumatologia dos Evangelhos é gradual, pois só paulatinamente se vai compreendendo que o Espírito não estaria com Jesus apenas em sua atividade pública, quer dizer, no ato de seus milagres e prodígios, e sim durante toda a sua vida, no arco total de sua existência terrena. Textos como Lucas 3,51-52 (infância), ou mais detalhadamente, Lucas 1,41 (feto) e Lucas 1,35 (concepção), são habilmente estratégicos em demarcar que a vida de Jesus é espiritualmente integral, inclusa a hora de sua morte, quando "a partir dessa Hora, a missão de Cristo e do Espírito passa a ser a missão da Igreja" (CAT: 730).

Sendo Jesus também o Cristo, não lhe é raro sugerir, em vários diálogos, a unção no Espírito (CAT: 728), ou ainda, prometer a sua vinda (CAT: 729). Assim, também no sentido de unção se assiste ao propósito de visualizar a causa formal que faz de todas as ações de Jesus um ato eclesiogenético: o termo Cristo não é um cognome de Jesus, tampouco um título, e sim uma profissão de fé, uma declaração pela qual se afirma ser Jesus o Ungido; isso denota uma presença sobrenatural junto a sua pessoa, e confere motivação e fundamento à adesão de seus seguidores (CAT: 690). Além do mais, a unção é a pré-condição de legitimidade para que qualquer gesto, seja o mais simplório, esteja carregado de eficácia redentora ${ }^{7}$.

$7 \quad$ As ações de Jesus se dignificam como gestos na medida em que se trate de ações ungidas, pois a unção de Jesus é o Espírito nele. São Gregório de Nissa (apud CAT: 690) explicava: "a noção da unção sugere... que não existe nenhuma distância entre o Filho e 
É o que se observa em inúmeras ocorrências nas páginas bíblicas. Em várias passagens, os gestos acompanham o agir de Jesus na forma de movimentos sutis. Estender a mão e tocar o leproso (Mt 8,3), tocar a mão da sogra de Pedro (Mt 8,15) ou os olhos dos dois cegos (Mt 9,29; 20,34), e apenas tomar a mão da adormecida filha do rabino (Mt 9,25) não apenas precede o efeito taumatúrgico, como traduz uma notável simplicidade. Tais sutilezas, como no fato do deixar-se tocar pela mulher hemorroísa (Mt 9,20; cf. Mt 14,36), constituem uma linguagem precisamente discriminada, a ponto de a imposição das mãos não se circunscrever à espontaneidade, mas ter-se conservado como gesto ritual na Igreja ${ }^{8}$.

Noutra sequência de relatos, um gesto não se distingue pontualmente pela realização de um singelo movimento corporal, mas se refina ainda mais ao suster da palavra. É desta forma, mediante uma determinação verbal, que os dois possessos gadarenos são libertos (Mt 8,32), o paralítico se levanta da maca (Mt 9,6-7) e a mão ressequida de um homem é recuperada (Mt 12,13). A fala ungida de Jesus é um autêntico gesto de cura e libertação (Mt 8,16), a se comparar com a ineficiência quase fraudulenta dos escribas e fariseus que dizem, mas não fazem (Mt 23,3).

Queremos também avaliar como autênticos gestos aquelas moções interiores (paixões) que, sem levantar sobre elas algum tipo de juízo moral, não escapam à apurada observação dos Evangelhos. Por conta disso, podemos hoje saber que Jesus se encheu de admiração ao ouvir o centurião de Cafarnaum interceder por seu servo (Mt 8,10), bem como ficou tomado de compaixão antes de tocar os olhos dos dois cegos de Jericó (Mt 20,34); mas também se indignou com os vendedores no Templo (Mt 21,12), zangou-se com seus discípulos (Mc 10,14) e até mesmo se irritou, conforme alguns manuscritos, quando na cura de um leproso (Mc 1,41.43). Externando profunda lástima, também chorou (Lc 19,41; Jo 11,33.35), vindo enfim a conhecer extremos de angústia (Mt 26,37-38; Lc 22,44) e abandono (Lc 27,46).

E em mais um passo desse esquema gradual, os gestos se detêm na simples presença de Jesus em certos ambientes. É marcante e traz muitas

o Espírito. Com efeito, da mesma forma que entre a superfície do corpo e a unção do óleo nem a razão nem os sentidos conhecem nenhum intermediário, assim é imediato o contato do Filho com o Espírito, tanto que, para aquele que vai tomar contato com o Filho pela fé, é necessário encontrar primeiro o óleo pelo contato".

$8 \quad$ Isso se verifica na Antiga Aliança (Lv 9,22; 16,21), reapropriada por Jesus (Mt 9,18; Mc 5,23; 7,32) e transmitida aos apóstolos (At 9,17). Inclusive Tiago 5,14 é usado liturgicamente para introduzir o rito da Unção dos enfermos (Ritual Romano, 2000: 34-35, n. 69), do qual faz parte a imposição das mãos sobre a cabeça do doente (Ritual Romano, 2000: 40, n. 74).

VERITAS, No 36 (Abril 2017) 
ressonâncias, mediante a perspicácia destes gestos, que Jesus se faça presente na coletoria de impostos ou banqueteando na casa de um coletor (Mt 9,9-10), monte um jumento à entrada de Jerusalém (Mt 21,7) ou vá à Samaria (Jo 4,4), frequente o templo (Mt 21,12) e a sinagoga (Lc 4,16) ou compareça a um lugar (a piscina de Betzatá) onde se cultuava o deus pagão Serápis (Jo 5,2), enfim, colha e coma espigas de trigo no sábado (Mt 12,1) ou lave o pé dos discípulos (Jo 13,5).

Mostramos suscintamente essa rede de circunstâncias para afirmar que, desde a admissão do ponto de vista formal, em cada gesto desses se forma Igreja. O parecer pode soar, num primeiro momento, um disparate, principalmente porque é um costume quase acrítico aquele que só atina para a fundação da Igreja em discursos que incluem, por exemplo, a escolha dos Doze (cf. Mt 10), ou a instituição da Eucaristia na última ceia (cf. Mt 26), ou o Pentecostes (At 2 em consonância a Lc 24,45-49). A causa formal de fato solicita que o discurso sobre a fundação da Igreja se respalde na multiplicidade das ações de Cristo, na totalidade de seu agir enquanto ungido, de sorte que a autocompreensão eclesial também sentirá os efeitos dessa inserção, como a seguir demonstraremos.

\section{A constituição da Igreja segundo a diferença formal especifica- dora}

Procedente é o uso do conceito de "forma" para a explicitação da ekelesia. Do mesmo modo que a forma é o que concorre para constituir a "parte intrínseca determinante e especificadora" (Jolivet, 1982: 284) de uma matéria, o qualificativo eclesial é o que convém para se declarar, conscientemente, que numa matéria qualquer (enquanto coisa ou princípio determinável) se configura a Igreja mediante o ato ungido do Cristo. A forma eclesial não é portanto uma mera adjetivação, mas "o fundamento da diferença específica" (Jolivet, 1982: 114), quer dizer, o caráter essencial que situa um ser numa dada espécie, ou o discrimina segundo um conjunto de propriedades ou caracteres; no caso, aquilo que perfila a Igreja ante um leque de outras organizações, associações, grupos ou comunidades.

Assim como trabalhamos a relevância da noção de causa formal no discurso sobre a fundação, é oportuno averiguarmos sua pertinência também a respeito da constituição da Igreja. Sob esse título, presenciamos o quanto está implícita a mesma conceituação quando se aborda a dupla natureza - visível e invisível - da Igreja. Que contribuições ainda se resguardam na perspectiva de sua aplicação? Como pensar a constituição da Igreja nos termos da causa formal?

Uma das afirmações contemporâneas mais notórias sobre o chamado "mistério da Igreja” se localiza no capítulo 1 da Lumen Gentium: "[A Igreja] 
não pode ser considerada duas coisas, mas uma única realidade complexa, composta de dois elementos, o humano e o divino" (LG: 8). Dizendo que a Igreja é ao mesmo tempo uma realidade visível e invisível, o Concílio confere um acabamento a pronunciamentos pontifícios anteriores. Um deles é o do Papa Pio XII na Mystici corporis (MC), de 1943. Por essa encíclica vemos a urgência de uma declaração acerca da natureza histórica e espiritual da Igreja, pois elimina um perigo de base: o de considerá-la "simples instituição humana com determinadas leis e ritos externos, mas sem comunicação de vida sobrenatural" (MC: 62), a Igreja jurídica; e em outro extremo, tomá-la exclusivamente como algo invisível e escondido, a Igreja ideal (MC: 63), jamais identificada a manifestações de ordem social, institucional ou ritual.

A instalação dessa dicotomia também é rebatida pelo Catecismo (CAT: 771) no parágrafo que antecede sua esquemática recapitulação da Lumen Gentium. Lê-se: "A Igreja está na história, mas ao mesmo tempo a transcende. É unicamente 'com os olhos da fé' que se pode enxergar em sua realidade visível, ao mesmo tempo, uma realidade espiritual, portadora de vida divina" (CAT: 770). Tais elaborações, no intuito de exprimir o mistério da Igreja, têm como prioridade retratar sua "complexa realidade" no aspecto constitucional ${ }^{9}$.

É claro que a atenção aos elementos constitutivos da Igreja requer um rigor descritivo que torna relativamente simples esquematizá-lo numa tabela. Sua estrutura hierárquica e organização territorial, com código de leis e corpo doutrinal, fazem da Igreja um fenômeno humano, sociologicamente empírico, historicamente verificável até o ponto em que, à luz da fé, é também a Igreja vista como enriquecida de bens celestiais, ornada de carismas, por onde se dá efetivamente a comunicação da graça e a efusão de dons sobrenaturais.

“[...] deve-se ter presente que a essência da Igreja não é perceptível em 'estado puro', mas existe somente nas suas concretizações históricas, nas quais deve ser apreendida. Esta perspectiva evidencia que na Igreja se distingue o que diz respeito à estrutura essencial e o que se refere à sua figura concreta: a primeira compreende tudo aquilo que deriva da sua instituição divina; a segunda, as contingências da história. Aliás, a estrutura essencial é sempre e somente perceptível nas formas concretas da configuração histórica que, embora assumindo formas diversas ao longo do tempo, não são indiferentes ou neutras com relação à estrutura essencial” (Lanza, 2000: 147. Tradução nossa).

VERITAS, No 36 (Abril 2017) 


\begin{tabular}{|c|c|}
\hline \multicolumn{2}{|c|}{ Igreja } \\
uma única realidade complexa de... & (LG: 8; CAT: 771) \\
\hline Natureza visivel & Natureza invisível \\
\hline concretização histórica & estrutura essencial \\
\hline contingência da história & instituição divina \\
\hline múnus jurídico (corpo) & missão do Espírito (alma) \\
\hline elemento humano & comunidade invisível \\
\hline grupo visível de pessoas & corpo místico de Cristo \\
\hline sociedade hierarquicamente estrutu- \\
rada & cumulada de bens celestiais \\
\hline realidade social &
\end{tabular}

Tabela: Natureza visível e invisível da Igreja segundo a constituição

Uma maneira de se ver ratificada a constituição da Igreja nos moldes das naturezas visível e invisível está patente na combinação que Paulo VI, na Ecclesiam suam (ES), articula com duas imagens: a da construção refletindo a parte visível do composto, e a do corpo místico, a parte invisível ${ }^{10}$. Com isso, tem-se manifesta a natureza íntima da Igreja: a ideia de "Corpo Místico de Cristo" exprime a "divina instituição" e o "santo canal" que, com a assistência da "hierarquia eclesiástica", as "comunicações admiráveis" da verdade e da graça de Cristo são derramadas sobre os membros da "organização visível” que, "peregrina no tempo", reflete uma "unidade ilustre, a funcionalidade orgânica, a variedade harmônica e a beleza espiritual", para utilizar palavras da Ecclesiam suam (ES: 16).

Mais do que qualquer outra entidade, é a Igreja quem está intencionalmente referida ao acontecer do Reino de Deus; mas isso se nutre da sensibilidade em notar que os bens celestiais que passam por ela só se realizam enquanto contribuições para o progresso e a união da humanidade. Embora "só a fé percebe esta compenetração das sociedades terrena e celestial" (GS: 40) de que se compõe a Igreja, exprime a Gaudium et spes, o binômio visibilidade-invisibilidade também se reporta ao entrelaçar do caminho da Igreja ao destino dos homens, com a Igreja "agindo como fermento ou como alma da sociedade humana" (GS: 40), ao modo de todo

10 "As imagens não conseguem traduzir-nos, em conceitos acessíveis, toda a realidade e profundeza deste mistério. Ainda assim, depois da imagem recordada do Corpo Místico, sugerida pelo Apóstolo São Paulo, deveremos fazer especial menção de outra, porque é do próprio Cristo: a do edifício de que ele é arquiteto e construtor; edifício fundado sobre um homem, frágil por natureza, mas por ele transformado milagrosamente em pedra sólida, isto é, dotado de prodigiosa e perene indefectibilidade: 'sobre esta pedra edificarei a minha Igreja' (super hanc petram aedificabo Ecclesiam meam - Mt 16,18)” (ES: 16). 
cristão: "o que a alma é para o corpo, são os cristãos para o mundo" (Epist. ad Diognetum apud LG: 38$)^{11}$.

Se há, então, o fato teológico da constituição visível-invisível da Igreja, matéria de reverberados debates é a maneira como ambas as naturezas se interagem ou se articulam. Logo nos deslocamos do terreno seguro da tópica para nos aventurarmos nas águas caudalosas da dinâmica, justamente onde no discurso eclesiológico abundam tantos conflitos... desde a Antiguidade $^{12}$.

O jovem Ratzinger vislumbrou a realidade eclesial segundo a ótica formal, quando na terceira parte de sua Introdução ao cristianismo, "O Espírito e a Igreja", averigua uma interferência que se interpôs no modo de se compreender o Símbolo. A "unidade de história e ser" (Ratzinger, 2005: 244) sempre foi crucial ao pensamento cristão original, mas a cisão entre ontologia e história seria drástica, a ponto de acarretar um grave deslocamento: de uma visão mais dinâmica da Igreja como lugar da ação do Espírito no mundo (concepção eclesial pneumatológica), tal como primordialmente considerada no Credo, para uma imagem mais estática da Igreja como organismo visível, tal qual corpo de Cristo (concepção eclesial cristológica).

Como o Espírito não é visto aqui [no Símbolo] como pessoa intradivina e sim como poder de Deus dentro da história que começou com a ressurreição de Jesus, deu-se na consciência dos fiéis uma interferência entre a profissão de fé no "Espírito" e a profissão de fé na Igreja. Trata-se, aliás, de uma aplicação prática da interferência [...] entre Trindade e história da salvação. [...] Em vez de ser interpretada como carismático-pneumática, a Igreja passou a ser entendida exclusivamente à luz da encarnação, fechada numa perspectiva

11 Vale dizer que na Sacrosanctum Concilium (SC), não obstante, a natureza visível-invisível da Igreja serve de princípio para o ordenamento da realidade mundana ao horizonte superior da eternidade: "Ela [a verdadeira Igreja] é, ao mesmo tempo, humana e divina, visível, mas dotada de bens invisíveis, presente ao mundo, mas peregrina, de tal forma que o que nela é humano está subordinado ao que é divino, o visível ao invisível, a ação à contemplação e o presente à futura comunhão que todos buscamos (SC: 2)

12 Segundo Ulrich Kühn (2004: 855), o desacordo entre Hipólito de Roma e o papa Calixto I sobre a pertença de pecadores na Igreja traduz "a tensão que reina entre a Igreja verdadeira e sua realidade material-institucional". Séculos adiante, na compreensão antireformista de Belarmino prepondera os elementos de visibilidade (a estrutura hierárquica, autoridade papal, a confissão da mesma fé, a participação nos mesmos sacramentos...) (Kühn, 2004: 857, 859) que replicam a diferença luterana entre a "Igreja compreendida como assembléia visível [...] e a Igreja verdadeira, compreendida como comunhão dos corações no Espírito Santo" (Kühn, 2004: 857), como também a eclesiologia de Calvino sobre a Igreja verdadeira, da pura pregação e da administração dos sacramentos, oposta à falsa Igreja papal (Kühn, 2004: 857).

VERITAS, Nº 36 (Abril 2017) 
terrena, vendo-se por fim explicada totalmente dentro das categorias do poder de um pensamento preso às coisas do mundo. Com isso ficou deslocada também a doutrina do Espírito Santo (Ratzinger, 2005: 244-245).

A profissão de fé no Espírito "não remete em primeiro lugar ao Espírito Santo como terceira pessoa na divindade e sim ao Espírito Santo como dom de Deus conferido à história da comunidade daqueles que crêem em Cristo" (Ratzinger, 2005: 243), quer dizer, como "poder pelo qual o Senhor elevado continua presente na história do mundo como o princípio de uma nova história e de um novo mundo" (Ratzinger, 2005: 244). Isso harmoniza notavelmente uma "concepção totalmente teocêntrica da Igreja” (Ratzinger, 2005: 246) -forjada a partir da dádiva de Deus que enriquece uma comunidade humana pautada no perdão (Batismo) e na comunhão (Eucaristia) - com um processo intra-histórico e completamente real: o ponto de partida para a doutrina da Igreja torna-se o Espírito Santo e seus dons, não a humanidade de Cristo (no que levaria a interpretar a Igreja numa perspectiva excessivamente intramundana); e no artigo de fé, vê-se a Igreja entendida "a partir do Espírito Santo como o lugar em que ele atua neste mundo" (Ratzinger, 2005: 246).

Isso evidencia que na compreensão sobre a constituição da Igreja também urge a noção da causa formal, no sentido mesmo de princípio que, unindo-se a uma matéria, produz o ser de uma dada espécie, a exemplo da espécie humana: "a diferença específica do homem (animal racional) será o caráter de racional, que define a forma substancial do homem ou alma racional" (Jolivet, 1982: 114). Concomitantemente, dá-se o nome de Igreja somente ao caráter de eclesial que define uma comunidade nessa forma substancial. Assim como, segundo a formalidade, "a alma humana, se acrescendo ao corpo, faz dele um ser humano" (Jolivet, 1982: 284), analogamente o Espírito se une à comunidade dos homens/fieis, para fazer dela Igreja ${ }^{13}$.

A causa formal infere um ato determinante que transforma um composto de corpo-alma em um ser humano; da mesma maneira a pesquisa em Eclesiologia, impelida pelo aspecto da formalidade, não há de satisfazer-se com o dado descritivo em torno às duas naturezas, e sim empenhar-se numa percepção mais aguçada da forma eclesial sendo ininterruptamente engendrada pelo Espírito de Jesus. É precisamente esse o intento da Lumen Gentium no seguinte parágrafo: "Compara-se, pois, em profun-

13 A exemplo desta análise de Pio XII: "nenhuma oposição ou contradição pode haver entre a missão invisível do Espírito Santo e o múnus jurídico dos pastores e doutores recebido de Cristo; pois que as duas coisas, como em nós o corpo e a alma, mutuamente se completam e aperfeiçoam e provêm igualmente do único Salvador nosso" (MC: 63). 
didade, com o mistério do Verbo encarnado. Assim como a natureza humana, assumida pelo Verbo divino qual instrumento vivo da salvação, o serve, estando-lhe intimamente unida, a realidade social da Igreja está a serviço do Espírito de Cristo, que a anima, em vista do crescimento do corpo (cf. Ef 4,16)" (LG: 8).

Tal como a natureza humana (visível) fazia as vezes de instrumento vivo da salvação operada pelo Verbo divino (invisível), a realidade social (visível) da Igreja está a serviço do Espírito de Cristo (invisível) que a anima. Em outras palavras: o Verbo é para a natureza humana de Jesus o que o Espírito Santo é para a realidade social da Igreja. Isso significa que o Espírito é a "alma” (ou o princípio vital) que confere a um corpo social a forma chamada "Igreja". O Catecismo ensina que "a unidade da alma e do corpo é tão profunda que se deve considerar a alma como a 'forma' do corpo" (CAT: 365); por sua vez, o corpo místico de Cristo teria recebido do Espírito, em plenitude de força e comunhão com o Filho, a forma invisível que se ia imprimindo à Igreja enquanto Jesus, peregrinando sobre a terra, realizava sua obra visível lidando com as multidões, as autoridades etc.

Já estamos bastante familiarizados com a relação da Igreja com Cristo pela imagem do corpo místico e sua Cabeça (1Cor 11,3; Ef 1,22; Cl 1,18 etc.). Todavia, seguindo as projeções do excerto acima, sentiríamos instigados a completar a metáfora antropológica: o corpo (Igreja) é unificado pela cabeça (Filho) e vivificado pela alma (Espírito), antes de tudo chamado à existência por um ato de criação e, à santidade por um ato de eleição (Pai).

Isso nos sugere um desenvolvimento no estudo em Eclesiologia que, concedendo menos à categorização (apologética) dos constitutivos da Igreja, assembleia visível e comunidade espiritual, daria mais atenção às relações da Igreja com o próprio mistério da Trindade. Nesse aspecto, a pergunta pela causa formal é também uma questão pneumatológica, no sentido de -como entendera Paulo VI $(1987)^{14}$ - complementar a eclesiologia do Concílio com um estudo e culto renovados do Espírito Santo, qual alma/forma do corpo-Igreja.

\section{Conclusão}

Mediante a causa formal conseguimos multiplicar os focos de incidência da ação fundante de Cristo. Não hesitamos em afirmar a urgência de

14 Citado em sua "Audiência geral de 6 de junho de 1973" por João Paulo II na Carta encíclica Dominum et vivificantem (n. 2).

VERITAS, Nº 36 (Abril 2017) 
se ressaltar a formalidade na estimativa sobre a instituição da Igreja: enquanto um congregado do pequeno número dos que responderam positivamente ao chamado da salvação, ela intermedeia o nexo entre a causa (Jesus) e o efeito (Reino), pelo fato (bíblico, histórico e existencial) de os homens não entenderem, não assentirem ou mesmo se oporem à BoaNova. Se a causa final lida com esses obstáculos clamando pela superação, faz-se mister também um ponto de vista, neste caso o da causa formal, pelo qual há de se evocar o aspecto da condução: "A Igreja é ao mesmo tempo caminho e finalidade do desígnio de Deus" (CAT: 778). Enquanto a causa final atua no sentido da consumação do Reino, a causa formal trabalha a condição de que o Reino não está ainda consumado.

A ênfase na causa final permite à Igreja abraçar cada vez mais sua vocação e se envolver mais intensamente com sua missão, na medida em que se torna mais consciente de sua origem. Essa perspectiva demonstra a importância de se manter vigente o princípio da Igreja, típico da finalidade, precisamente para que não se faça dela um fim em si mesmo. $\mathrm{O}$ ponto de vista da causa final arquiteta um panorama frontal da Igreja, permitindo uma análise sempre atualizada pela qual o sujeito eclesial é avaliado se está em harmonia ou se extraviando de sua meta. Nesse parâmetro, a Igreja é percebida em ordem a seu propósito maior, bem como mobilizada em função de um empenho soteriológico.

Se desmedidamente empregada, causa final inclina para uma expectativa utópica e passível de frustração. Em vista da vitória final, tudo parece se encaminhar resolutamente para a glorificação celeste, na eterna Jerusalém e com o pleno advento do Reino. Garantido o para que, pouca atenção se dá ao como. Sucede, por conseguinte, que uma estratégica expressão, o tempo da Igreja, seja arrombada por um humor triunfalista que a esvazia de todo o seu caráter formal.

Importantes são as ressonâncias que a promoção da causa formal traz para o discurso eclesiológico sobre a fundação da Igreja. Ela permite perceber que os gestos de Jesus, enquanto gestos ungidos por seu Espírito, portam a forma eclesial. É compreensível que, numa multiplicidade de ações, queira-se eleger mais especificamente uma ou outra a fim de se atender à perspectiva da causa final. Todavia, quanto à causa formal, torna-se mister reconhecer a gênese da Igreja em tudo o que o Senhor fez, sentiu e falou. O princípio mariano é assim oriundo daquela mesma atitude que Lucas reconhece em Maria, quem guardava todas as coisas no coração (Lc 2,51b).

Tanto na demarcação da pneumatologia dos Evangelhos como no sentido de unção se assiste ao propósito de visualizar a causa formal, que nos traduz todas as ações de Jesus como um ato eclesiogenético. Além disso, a convergência entre a etimologia de igreja e a conveniência do desejo 
no princípio da causa final marca com mais intensidade o tom de uma intencionalidade de Jesus em querer fundar a Igreja. Logo é espontâneo pensarmos que nesse processo laboral participaram tanto as mãos (visíveis, materiais) do carpinteiro, como também a projeção visionária (invisível, espiritual) que antecipa à mente a realização de uma obra futura. Ou seja: no trabalho de edificação da Ecclesia cristã, enquanto Jesus a modela visível e historicamente com seus gestos e palavras, seu Espírito o faz em termos de projeto mental, preparando à sua conveniência o Templo em que viria habitar.

É assim que, sublinhando a causa final no modo de se entender a instituição da Igreja, também abrimos espaço para conjecturar a possibilidade de se discorrer a partir de outro aspecto, a causa formal, perguntando-nos: como seria a fundação da Igreja nessa ótica? Que contribuições esperaríamos do ponto de vista da formalidade, ou que ficam supostamente empalidecidas quando não somamos essa dimensão ao discurso sobre o nascimento da Igreja?

Pela mesma via se emite uma interpelação pastoral a toda alma que se dedique a penetrar o mistério da Igreja: uma vez chamado a ser "membro" do corpo de Cristo (1Cor 6,15; 12,12.27; Rm 12,15), como me situo na ação pela qual o Espírito de Jesus imprime sua forma a fim de engendrar Igreja? Onde, em minha pessoa, encontro o ponto de inflexão no qual o discurso teológico sobre a constituição da Igreja se reverte no íntimo en-

gajamento por uma vida mais espiritual e, por assim dizer, mística? Tais indagações tornam-se eficazes quando se assume o ponto de vista formal, pelo qual se adquire mais do que um conhecimento teológico, pois se apreende uma experiência conatural: "A consciência do mistério da Igreja é um fato próprio da fé adulta e vivida. Produz nas almas aquele 'sentir da Igreja', que penetra o cristão formado na escola da palavra divina, alimentado pela graça dos sacramentos e pelas inspirações inefáveis do Espírito Paráclito" (ES: 16).

\section{REFERÊNCIAS}

-Catecismo da Igreja Católica (1999). São Paulo: Loyola.

-Concílio Vaticano II (2007). Concílio Vaticano II, Vaticano II: mensagens, discursos e documentos [Constituição dogmática Lumen Gentium sobre a Igreja, pp. 185247; Constituição pastoral Gaudium et spes sobre a Igreja no mundo de hoje, pp. 470-549; Constituição Sacrosanctum Concilium sobre a Sagrada Liturgia, pp. 141-175; Decreto Ad gentes sobre a atividade missionária da Igreja, pp. 400439]. São Paulo: Paulinas. 
-Congregação para a Doutrina da Fé (2007). Declaração Dominus Iesus sobre a unicidade e a universalidade salvífica de Jesus Cristo e da Igreja. Em H. Denzinger \& P. Hünermann (Orgs.), Compêndio dos símbolos: definições e declarações de fé e moral (pp. 1223-1230). São Paulo: Paulinas: Loyola.

-Francisco (2014). Exortação apostólica Evangelii gaudium: sobre o anúncio do Evangelho no mundo atual (Segunda edição). São Paulo: Paulus; Loyola.

-João Paulo II (1996). Redemptoris missio: carta encíclica sobre a validade permanente do mandato missionário. Em L. Sartori (Org.), Encíclicas do Papa João Paulo II: o profeta do ano 2000 (pp. 337-399). São Paulo: LTr.

-Jolivet, R. (1982). Curso de Filosofia (Décima quarta edição). Rio de Janeiro: Livraria Agir.

-Kehl, M. (1997). A Igreja: uma eclesiologia católica. São Paulo: Loyola.

-Konings, J. (2005). Sinopse dos Evangelhos de Mateus, Marcos e Lucas e da "Fonte Q". São Paulo: Loyola.

-Kühn, U. (2004). Igreja. Em J. Y. Lacoste (Dir.), Dicionário crítico de Teologia (pp. 852-865). São Paulo: Paulinas; Loyola.

-Lanza, S. (2000). Chiesa. Em A. Boroli \& M. Drago (Orgs.), Enciclopedia del Cristianesimo: storia e attualità di 2000 anni di speranza (Sétima edição, pp. 147-155). Novarra: Istituto Geografico De Agostini.

-Lauand, J. (2012). A filosofia da educação no Catecismo da Igreja Católica. Guia prático de teologia (1), 22-35.

-Leahy, B. (2005). O princípio mariano na Igreja. Vargem Grande Paulista: Cidade Nova.

-Paulo VI (1997). Ecclesiam suam. Carta Encíclica sobre os caminhos da Igreja (Terceira edição). São Paulo: Paulinas.

-Paulo VI (1973). Udienza generale, 6 giugno. Recuperado de http://w2.vatican.va/content/paul-vi/it/audiences/1973/documents/hf_pvi_aud_19730606.html.

-Pio XII (1998). Mystici Corporis Christi. O Corpo de Cristo e nossa união nele com Jesus Cristo. Em D. L. Marin (Coord.), Documentos de Pio XII: 1939-1958 (pp. 140-199). São Paulo: Paulus.

-Prete, V. Del (2010). A boa terra: reflexões sobre a evangelização. Roma: Secretariado Internacional da Pontifícia União Missionária.

-Ratzinger, J. (2005). Introducão ao Cristianismo: preleçães sobre o Simbolo Apostólico. São Paulo: Loyola.

-Ritual Romano (2000). Ritual da Unção dos enfermos e sua assistência pastoral (Oitava edição). São Paulo: Paulus.

-Schmidt, K. L. (1965). Igreja. Em G. Kittel (Ed.), A Igreja no Novo Testamento (pp. 15-63). São Paulo: Aste.

-Warnach, V. (1988). Igreja. Em J. B. Bauer (Org.), Dicionário de Teologia Bíblica (Quarta edição, Vol. I, pp. 485-504). São Paulo: Loyola.

Sumário: Introdução; 1. A noção de causa final no discurso eclesiológico; 1.1. O papel moderador da causa final na relação entre o Reino e a Igreja; 1.2. A causa final no discurso sobre a fundação da Igreja; 2. A fundação da Igreja no ponto 
de vista da causa formal; 2.1. A causa formal no "tempo da Igreja"; 2.2. A fundação da Igreja na formalidade dos gestos de Jesus; 3. A constituição da Igreja segundo a diferença formal especificadora; Conclusão; Referências. 